\title{
The Irish in American Cinema 1910 - 1930: Recurring Narratives and Characters
}

\author{
THOMAS JAMES SCOTT, University of Ulster
}

\begin{abstract}
This paper will consider cinematic depictions of the Irish between 1910 and 1930. American cinema during these years, like those that preceded them, contained a range of stereotypical Irish characters. However, as cinema began to move away from short sketches and produce longer films, more complex plots and refined Irish characters began to appear. The onscreen Irish became vehicles for recurring themes, the majority of which had uplifting narratives. This paper will discuss common character types, such as the Irish cop and domestic servant, and subjects such as the migration narrative, the social reform narrative and the inter-ethnic comedy. It will also briefly consider how Irish depictions in the 1910s and 1920s compared to earlier representations. While the emphasis will be on films viewed at archives, including the University of California, Los Angeles Film and Television Archive, or acquired through private and commercial sellers, the paper will also reflect on some films that are currently considered lost.
\end{abstract}

\section{KEYWORDS}

Irish, cinema, representation, stereotypes, migrants.

\section{Introduction}

Feature Productions' early 'talkie' Irish Fantasy (Orville O. Dull, 1929) should be considered important for two reasons. One, it is one of the earliest Irish-themed musicals to survive in its entirety. Two, it was produced by William Cameron Menzies, who would go on to win an Academy Award for his production design on MGM's Gone With the Wind (Victor Fleming, 1939). The film centres on an old Irish man explaining the meaning of the three leaves of the shamrock to his uninformed grandson, who remarks 'sure they're only weeds.' The first leaf signifies what the Irish are, 'happy-go-lucky with warm blood in our hearts.' The second symbolises the big hearts of the Irish who were forced to migrate to America. Finally, the third represents the Irish who battled the British for Ireland's freedom. The film is one of the most clichéd depictions of Ireland and the Irish produced between 1910 and 1930. Every character is dressed in attire that wouldn't look out of place on the 'little people' in Disney's Darby O'Gill and the Little People (Robert Stevenson, 1959) - the grandfather's attire, for example, is curiously similar to the clothes worn by King Brian (Jimmy O'Dea), the leader of the little people. Additionally, the Irish village is depicted as a kind of rural utopia complete with a beautiful forest by the sea, villagers dancing Irish jigs in the cobblestone streets and wild fowl, including ducks and swans, roaming freely. While the film is not necessarily a negative depiction and contains themes which would appear frequently in the 1910s and 1920s (emigration, the close-knit Irish community, the British occupation of Ireland), this 
romanticised version of Ireland and the parodied Irishness found within it is not illustrative of the most common representations found in the 1910s and 1920s.

I first viewed Irish Fantasy at the University of California, Los Angeles (UCLA) Film and Television Archive in April of 2012. ${ }^{1}$ I later discovered that the film was made commercially available, hidden away as a bonus feature on a DVD collection titled The Fantastic World of William Cameron Menzies (2009). This is fortunate, as a significant amount of Irish-themed films produced during the earliest years of the American film industry are either lost or locked away in various film archives making it difficult for the researcher working in this subject field to view a large amount of early films without significant cost, and/or travel. Yet despite the commercial availability of Irish Fantasy it has not been examined in existing texts on the Irish in American cinema (although it is listed in Kevin Rockett's (1996) Irish Filmography: Fiction Films 18961996). Until my research, it has, therefore, gone somewhat undetected. Irish Fantasy is just one of the Irish-themed films that are yet to be studied by researchers examining the portrayal of the Irish in American cinema and it is a signal of the work that still needs to be done - the sourcing and study of a broader range of films relevant to the field.

This article is not intended to be a comprehensive history of the Irish-themed film from 1910-1930, as this is not possible due to the amount of early films that have not survived. However, I will contribute to the on-going discourse on Irish cinematic representations, including the work of Rockett (1996; 2009) and Gary D. Rhodes (2012), by considering recurring images of the Irish from a range of films made between 1910 and 1930. I will do this through an examination of the recurring narratives and characters that dominated Irish-themed productions during these years. I will also consider how Irish portrayals between 1910 and 1920 compare to the Irish representations of earlier years.

\section{The Earliest Cinematic Depictions of the Irish}

Firstly, it is necessary to consider the earliest American cinematic depictions of the Irish. Early films generally contained crude Irish stereotypes such as the ham-fisted Irish female domestic servant, drunken Irish men, buffoonish Irish labourers and womanising Irish cops. Rhodes argues that these 'stage-Irish' depictions can be traced back to vaudeville and print media such as anti-Irish cartoons printed in magazines like Puck or Harper's Weekly $(2012,199)$. However, Jennifer Mooney argues that this does a disservice to vaudeville, as there was not one monolithic type of Irish character but rather a multifaceted and diverse array of representations (2013, 222-23). Early cinema, it seems, only inherited the disparaging representations, seemingly ignoring the constructive depictions to which Mooney refers. Harry M. Benshoff and Sean Griffin give a similar assessment to that of Rhodes, remarking that depictions 'drew upon already-established stereotypes and misconceptions developed in other media such as literature, newspaper cartooning and theatre' $(2004,59)$. Nevertheless, irrespective of where the inspirations came from, the earliest American films generally offered uncomplimentary representations. In the first year of the public exhibition of cinema, in Pat and the Populist (James H. White, 1896), an Irish labourer purposely drops bricks on a politician who displeases him. Irish Way of Discussing Politics (James H. White, 1900) depicts two hostile Irishmen disagreeing on many political topics until beer is introduced. In $A$ Wake in Hell's Kitchen (1900), an Irishman rises from a coffin to drink from a nearby glass of beer, leading to a mass brawl between the mourners. The drunken and/or aggressive Irish man still appears

\footnotetext{
${ }^{1}$ Accessible at http://cinema.library.ucla.edu
} 
between 1910 and 1930 but in later years this character trait was often eclipsed by better characteristics, or reserved for supporting characters. The Irish labourer was another common choice for onscreen derision. In both Blasting Rocks in Harlem (1901) and Brannigan Sets off the Blast (1906) a hapless Irish labourer accidently blows himself up due to his incompetence when dealing with explosives (Rockett 1996, 233 and 240).

The Irish female was not afforded much better treatment. In 1898, an idiotic Irish domestic servant appears in How Bridget Served the Salad Undressed. The 'How Bridget...' films, which appeared sporadically in the 1890s and 1900s, constantly centred on the activities of a blundering Irish woman. A calamitous housewife demonstrates her ineptitude in How Bridget Made the Fire (1900) when she attempts to light a stove and creates an explosion that sends her headfirst through the window (Rockett 1996, 231). Firing the Cook (1903) centres on a Bridget-like character who is fired when she breaks one of her employer's lavish dinner plates. When the employer asks a policeman to remove the cook from her home, the officer is thrown through a window by the Irish woman (Rockett 1996, 236). However, in other early films the Irish woman/Irish cop relationship was friendlier. In Policeman's Love Affair (1905), for example, an Irish cook flirts with an Irish cop named Michael McGinnis (Rhodes 2012, 201-02).

Irish politicians did not fare much better in early films. In When Women Vote (1907) it is implied that by dabbling in politics, an Irish woman is neglecting her responsibilities at home. As a result, the husband seeks a divorce (Rockett 1996, 243). Representations of male Irish politicians were equally as negative, even in the 1910s. When Hooligan and Dooligan Ran for Mayor (Wally Van, 1915) pokes fun at the election campaigns of two Irish men. Competing against one another, they use under-handed tactics in an effort to ruin each other's chances. In the end they are both ridiculed while a third candidate, an Anglo-American named Straightwater, wins the campaign. Paddy's Political Dream (John Francis Dillon, 1916) centres on a factory worker who falls asleep on the job and dreams that he is a political boss. During his term he receives bribes, associates with gangsters and rigs the voting (Rockett 1996, 288-90). The fact that the film is a comedy suggests it should not be taken seriously; however there is clearly a level of scepticism on display.

Idiotic labourers, drunken or aggressive 'paddies,' and buffoonish domestic servants continued to appear after 1910, although less frequently. Keystone's 'Hogan' film series (1914-1915), while not quite as pejorative as the short films of the previous decade, seemed to draw on some features of 'stage-Irish' characters. In Hogan's Mussy Job (Charles Avery, 1914) Hogan gets into a brickthrowing fight with other Irish labourers and in Hogan, the Porter (Charles Avery, 1915) he is depicted as a stereotypical drunken Paddy. Hogan was played by Irish character actor Charles Murray, a former Vaudevillian who had been in a similar set of films at Biograph before joining Keystone in 1914. Gary Rhodes states that having just played an Irishman in the series of films at Biograph, having Murray's name attached to the 'Hogan' series made the character readily identifiable as Irish $(2012,229-30)$. Murray would go on to play numerous Irish roles throughout his career including a recurring role in Universal's The Cohens and the Kellys film series (19261933) and an Irishman elevated from navvy to millionaire due to an inheritance left by his uncle in short comedy film The Duke of Dublin (William Watson, 1930) - this film, labelled 'an Irish comedy fest' by a Film Daily reviewer, is unfortunately no longer available (Anon. 1930). 


\section{The Emergence of Progressive Irish Characters}

Despite the negative aspects of these early Irish stereotypes, they flourished in early American films. By 1910, according to synopses in Rockett's Irish Filmography, at least 60 films contained a stage-Irish character such as the ham-fisted and aggressive Irish female domestic servant or the idiotic labourer (1996, 230-46). While stage-Irish stereotypes would never disappear entirely, positive Irish characters and more sophisticated narratives began to appear in the 1910s. The fact that so many early films are no longer available makes it difficult to define exactly when Irish depictions began to improve. However, we can certainly locate social and political factors behind the improvement. Lee Lourdeaux (1990), Lance Pettitt (2000) and Benshoff and Griffin (2004) argue that representations started to develop as public opinion on the Irish improved. Lourdeuax states that the Irish determination to succeed was pleasing to Anglo-Americans and the Irish became onscreen role models for the Eastern and Southern European immigrants $(1984,55)$. While outside factors are significant, I would also argue that the improving depiction had much to do with the longer duration of films and the need for more refined narratives in order to entice a 'higher class' of patron to cinema theatres. A longer running time allowed for deeper characterisation and more complex narratives. Thus, the emergence of a more refined Irish character and the less frequent appearance of the stage-Irish stereotype may have been influenced not only by the status of the Irish in American society, but also by changes in how cinematic narratives were constructed. While this theory certainly requires further research, it is plausible that these changes in the industry would have an impact on depictions of America's ethnic groups, including the Irish.

A useful starting point for the emergence of a more refined character is the Irish-themed work of Sidney Olcott. In A Lad From Old Ireland (1910) (the first fiction film made on location in Ireland), Olcott depicts a capable and hardworking Irish migrant, named Terry (played by director-actor Olcott), who travels from rural Ireland to industrial America. After rising from labourer to successful politician (a rare depiction) he returns to Ireland and rescues his poverty stricken girlfriend and her family. In addition to the positive representation of a male Irish immigrant, there is not a single hapless Irish character to be found in A Lad from Old Ireland. Olcott's collection of Irish-themed work, which included over 20 films shot on location in Ireland, comprised emigration narratives, adaptations of popular Irish plays and stories of Irish rebels battling British soldiers in rural Ireland. His Irish characters went a long way towards eliminating the stage-Irish from American cinema screens, a fact highlighted by Irish Times columnist David C. Fanning in 1961 who remarked that 'Olcott gave us the real Irish man, a being moved by emotions and by social considerations. For this alone, he should be thanked by Ireland' (Fanning 1961).

Independent Moving Picture's (IMP) Shamus O'Brien (Otis Turner, 1912), based on a poem by Joseph Sheridan Le Fanu, is about the eponymous real life hero of the Irish Rebellion. Kevin Rockett has remarked that the poem was very popular among Irish migrants in the USA and that Olcott's Rory O'More (1911) and For Ireland's Sake (1914) were also based on the poem (1996, 258). The Selig Polyscope Company's earlier Shamus O'Brien (Francis Boggs, 1908), as the name indicates, centres on the same Irish rebel as IMP's 1912 production (Rockett 1996, 244). The poem was popular with the Irish in America and this may have been a big reason behind several adaptations being produced. The fact that a lot of surviving Irish rebel films work with the same source material would also explain why the narratives always include the same characters; the rebel, the loyal girlfriend, the girlfriend's mother, the supportive village priest, British soldiers and a turncoat informer. These rebel films offered more complex, and positive, portrayals of the Irish including the Irish informer who despite his negative qualities still offered something different from the stage-Irish character. They presented images of brave and determined men and women willing 
to risk their lives for friends, family and country. A common and positive theme in these rebel films is the depiction of a close-knit and caring Irish community, a characteristic which is considerably amplified and enhanced by the image of the informer, a social outcast who illustrates how cohesive the rest of the Irish community is in comparison. The image of a close-knit Irish community would become a dominant theme in films set in Ireland, including the Irish-themed work of John Ford. It can also be found in the overly-sentimental and mawkish film Irish Fantasy, mentioned in my introduction. However, the severely idealised Ireland and the parodied Irish characters found within Irish Fantasy rather undermines it's more positive features.

\section{The Irish Migrant Story}

The decision that millions of Irish men and women took to leave their birthplace and start afresh in America demonstrated incredible courage and determination. Migration narratives displayed these qualities in abundance. While the subject could be found prior to 1910, in Caught by Wireless (Wallace McCutcheon, 1908), which starred D. W. Griffiths as an Irish migrant, it really came to prominence in the 1910s and 1920s. At least forty films made in these years contained the theme of Irish migration from the 'auld sod' to 'the land of opportunity' (see Rockett 1996, 247-332). How Molly Malone Made Good (Lawrence B. McGill, 1915) centres on a young Irish woman (Marguerite Gale) who arrives in America to live with her brother, a New York Tribune reporter. On the journey to the United States she befriends an opera singer based on the real Madame Fjorde (playing herself). After arriving at the Tribune, Molly finds that her brother has left to cover the war in Europe. While in the office, Molly overhears a reporter called Alva Tinton (Helen Hilton) claiming that Madame Fjorde was not on the Adriatic and as a result, she could not carry out her interview assignment. Molly senses an opportunity and claims that she can do the job. Molly is successful and the editor makes her an offer; if she can interview ten theatre stars in three days she will be given Alva's position. Despite Alva's endeavours to thwart the unwavering Molly, she completes the project and secures a position at the newspaper. Many migration plots end with the Irish boy or girl finding love. How Molly Malone Made Good is no different in this respect. Molly falls for a Tribune editor named Billy Morrison (James Bagley) who supported her throughout her assignment.

Although Molly's Irishness is of no real significance to the plot, she is nonetheless a progressive representation of an Irish woman, whose crossing from Ireland to America is presented in terms of positive social mobility and self-determination. Molly is an ideal immigrant determined to earn her way. This is quickly established in an early scene where Molly refuses the Tribune editor's offer of money and asks for a job instead. Her resolve is on show throughout the film as she finishes her project despite frequent obstacles including getting robbed, missing her train, rejecting the advances of an infatuated money lender, travelling during a powerful storm and surviving Alva's attempt to frame her as a purse snatcher. Molly finds it easy to mix with America's social elite and is invited to attend an upper class gathering where she meets a number of highly regarded people including the mayor of Ashbury Park and the Queen of the Carnival. The film does not make clear if Molly has come from a humble background in rural Ireland. However, it is possible that the cinema-goer in 1915 would have made this assumption, given that this was the norm for the onscreen Irish migrant during this period. Yet Molly is more educated than the typical onscreen Irish female during these years. While Irish female representation had already progressed beyond the 'Bridget' depictions discussed earlier, the presence of an Irish female reporter was uncommon. How Molly Malone Made Good should therefore be considered an important film, regardless of how little 'Irish' is in the central character. 
Conductor 1492 (Frank Griffin and Charles Hines, 1924) depicts a male Irish migrant as honest and brave, who can make a valued contribution to American society. Despite his initial plans to become a policeman, recently arrived Irish migrant Terry (Johnny Hines) decides to follow in his father's footsteps and finds a job as a trolley car conductor for the Loteda Traction Company. Similar to How Molly Malone Made Good, Conductor 1492 deals with Irish upward mobility. At first Terry finds integration awkward. Yet, by the end of the film he has achieved economic success and through his marriage to Edna (Ruth Renick), the daughter of the president of the traction company, has integrated into upper class American society. In a review printed in Virginia-based newspaper The Daily Star, the writer remarks, 'Who is Conductor 1492? Oh, just the fighting Irishman - did you ever see an Irishman who didn't love a good stiff set-to' (Anon. 1924). While Conductor 1492 is generally a positive depiction of Ireland and the Irish, it is not short of Irish stereotypes. In the opening scene two villagers cut short their game of horseshoe to argue about Terry's trip and the argument ends in a fistfight, naturally. In the film's final scene, after returning to Ireland, Terry gives every Irish villager boxing gloves as gifts and tells them to 'show yer nationality.' The villagers put on the gloves and a mass brawl begins. Yet as was often the case in Irish-themed films of this period, the Irish fondness for a punch up is depicted as a characteristic that could be beneficial. In an early scene, Terry removes a drunken and aggressive passenger from his carriage at the request of an unsettled female passenger. It is his father's (Dan Mason) aptitude for fighting that has the most productive outcome however. After arriving at Terry's American home in a police van, it is quickly revealed that he assisted the police in the capture of a large gang.

\section{The Social Advancement Narrative: The Irish and Upward Mobility}

By the end of How Molly Malone Made Good and Conductor 1492 the Irish character finds love with a middle, or upper class member of American society. This theme was common in early Irishthemed films. What this seems to propose is that the Irish migrant's integration into American society is assisted by a member of the higher classes. A large number of early Irish-themed films centred on the American-born girl of Irish immigrants and her desire to escape the daily humdrum of Irish tenement life. The stories of these lower class single young Irish women falling for rich American men were described as 'Cinderella narratives' by journalist Alma Whittaker in 1926:

There seems to be one sure-fire bet in both motion-pictures and stage plays, to say nothing of popular fiction. Cinderella must positively be a cute little Irish Mick these days if she is to win fame and the Prince Charming. Fairy godmothers have been specializing in these little lowly-born Irish girls, preferably from New York tenement districts. (Whittaker 1926)

Whittaker argues that Mary Pickford and Colleen Moore are obvious examples of actresses who had success playing the Irish Cinderella. Indeed, Amarilly of Clothes-Line Alley (Marshall Neilan, 1919) (starring Pickford), and Irene (Alfred E. Green, 1926) (starring Moore) are both solid examples of the 'Cinderella narrative.' Each film follows the rise of a lower class Irish girl into the upper classes via a relationship with a wealthy American male. Molly O' (F. Richard Jones, 1921) is another obvious example. In fact, the fairy-tale is referred to within the dialogue when Molly remarks 'I feel like Cinderella,' while getting a costume for an upper class dinner party. Additionally, a reviewer writing for The San Francisco Chronicle remarked that 'Molly O's appeal lies principally in the ever-popular attraction of the Cinderella theme' (Anon. 1921).

The Courage of the Commonplace (Rollin S. Sturgeon, 1913) also contains elements of the 'Cinderella narrative.' The short and relatively uneventful film centres on a young Irish-American girl named Mary (Mary Charleson), the eldest daughter of a large family that includes three 
younger sisters and two brothers. Mary works on the family farm but dreams of a better life while completing her monotonous daily chores. She wants to go to college, get married and have children. Yet the film ends with Mary giving up on her dreams and realising that her place is on the farm. It is likely that the ending of The Courage of the Commonplace was a result of the period in which it was made. While Irish representation began to improve during this period, it would be a few more years before upwardly mobile Irish women regularly appeared in American films. According to the information included in the listing on the UCLA Film and Television Archive's online catalogue, the film was shown at a sermon in San Francisco during a time when the church demonised the film industry. A Fresno minister claimed that god was present in Mary's sacrifice ${ }^{2}$. This rather unrewarding conclusion was a rarity, however, with the cheerier and more Cinderella-like ending far more common.

While early American films depict an inter-class relationship as the most common method of social transformation, a different style can be found in John Ford's Mother Machree (1928) where an Irish boy is adopted by a rich American family. Produced, written and directed by Hollywood favourite Marshall Neilan, Dinty (John McDermott and Marshall Neilan, 1920) is similar to Mother Machree. Dinty (Wesley Barry) is the son of an Irish woman who has just arrived in San Francisco. Shortly after arriving in the United States, Doreen O'Sullivan (Colleen Moore) learns that her husband was killed earlier that day in an automobile accident leaving her to care for Dinty alone. After she falls ill, Dinty takes a job selling newspapers to support them both. His hard work and fighting spirit sees him rise to become the head of the newsboys. When criminal Wong-Tai (Noah Beery) kidnaps Judge Whitely's (J. Barney Sherry) daughter (Marjorie Daw), Dinty, familiar with the layout of Chinatown, assists the capture of Wong-Tai by leading the police to his hideout. After Dinty's mother succumbs to her illness, the Judge shows his gratitude for the rescue of his daughter by adopting Dinty. Much like Johnny in Conductor 1492 and Molly in How Molly Malone Made Good, Dinty has all the characteristics to be successful but ultimately, needs upper class backing to truly fit in. Dinty's positive characteristics are alluded to in promotional material printed in the Fitchburg Daily Sentinel. It notes that 'Dinty is a character that will prove a model for your children, all his efforts are inspired by love of his mother. He presents a striking lesson in the duty a son owes to his parents' (Anon. 1920). Dinty is also notable for the amount of Irish-born cast members. According to a cast list printed in The Kokomo Daily Tribune, Irish actors were employed to play Dinty's mother, as well as the characters Mrs. O'Toole (Kate Price) and the district attorney Jack North (James Pat O’Malley) (Anon. 1920a).

\section{The Onscreen Irish and the American Melting Pot Philosophy}

A significant number of early films focused on the relationship between two culturally different groups. In the early films that could be considered Irish-themed, Irish-German, Irish-Dutch, IrishItalian and Irish-Jewish relationships were all explored. Timothy J. Meagher argues that the IrishJewish relationship was one of the oldest, and most popular, inter-ethnic subjects in American popular culture. He remarks that the combination became an 'obsession in American movies in the 1920s and early 1930s' (2009, 45). Ham and Herring (1927) centres on an Irish family (the O'Connors) and a Jewish family (the Goldbergs) and the romantic relationship of the young Irish daughter Lizzie (Marjorie Meadows) and the Jewish son Izzy (George Chapman). The plot revolves around the families' planned picnic to 'burn bridges'. Their love-hate relationship makes for an eventful story that involves an exciting race scene, where the two fathers compete with one another to reach the campgrounds first. The group mistake a fancy mansion, 'where they ate goldfish

\footnotetext{
${ }^{2}$ Accessible at http://cinema.library.ucla.edu
} 
instead of sardines in their sandwiches,' for a camping park and wreak havoc before the butler chases them off the property. The two families quickly pull together and escape before the mansion owners, the De Camps, return home. Ham and Herring seems to propose that the raucous working class, regardless of ethnicity, do not readily belong in upper class society, though their down to earth humour and boisterousness can sometimes bring an energy and humanity to the lugubrious sterility of upper class life.

Rockett believes that beneath the comical format of inter-ethnic comedies there lay a serious assimilative message that conflicting ethnic groups should put aside their differences for the good of society $(2009,21)$. The tumultuous relationship of an Irish and a Jewish family is the subject of the popular Cohens and Kellys comedy film series. The set of films was produced by Universal Pictures and ran from 1926 to 1933. The first of the series, The Cohens and the Kellys (Harry A. Pollard, 1926), tells the story of an Irish police officer named Patrick Kelly (Charles Murray) and a Jewish grocery store owner called Jacob Cohen (George Sidney) and their respective families. The family members include Tim Kelly (Jason Roberts Sr) and Nannie Cohen (Olive Hasbrouck), who are romantically involved and secretly get married despite their fathers' differences. Additionally, during the course of the narrative, Nannie gives birth to Tim's baby, creating further tension between the families. A reviewer in the Universal Weekly remarked that the majority of the comedy comes from the inability of the two families to get along: 'there is always war between the Irishman and the Hebrew. Even their boys fight; whenever one spies the other, they spring at each other like bulldogs' (Anon. 1926). By the end of the film, the Irish family and the Jewish family resolve their differences. Patrick and Jacob decide to go into business together and everyone lives happily ever after. There were seven 'Cohen and Kelly' films made in total. An eighth was announced in 1930 but never produced. According to an article in industry journal Film Daily, the film was, interestingly, to be titled The Cohens and the Kellys in Ireland (Anon. 1930a).

An inter-culture relationship is also the focus of The Man in Blue (Edward Laemmle, 1925). The narrative centres on Irish police officer Tom Conlin (Herbert Rawlinson) who lives and works in New York's Little Italy. Tom is in love with an Italian flower girl named Tita Sartori (Madge Bellamy), but their relationship is problematic. The fact that Officer Conlin is an Irishman in a district dominated by Italians is a major difficulty. Tita's father (Cesare Gravina) demands that she marries a fellow countryman and attempts to push her into a relationship with a crooked Italian politician named Gregorio Vitti (Nick De Ruiz). At Café Palermo, 'the centre of Little Italy's social and political life,' Vitti reads an article printed in an Italian language newspaper titled 'Secret Societies Control Electors'. Vitti orders two of his henchman to kill Captain Valento (Harry Mann), the editor of the newspaper. However, despite blowing up the newspaper office, Valento escapes unscathed. Officer Tom Conlin witnesses the explosion and sees three Italian mobsters fleeing from the scene. He pursues them and places two of the men under arrest. Later, despite her father's demands, Tita goes on a date with Tom. Gregorio Vitti believes Tita's father has disrespected him and, as a consequence, orders his men to 'take care' of him. When Tita returns and finds her father dead, Vitti explains that he had an accident and tells her that she can stay with him. Once at his home she is held captive and is forced to agree to marriage. On the day of the wedding however, Gregorio Vitti and a man called Carlo (André De Beranger) fight over Tita's hand in marriage. Vitti shoots and kills him but is arrested by Tom before he can flee, and Tita is freed. Later at the Café Palermo a mass brawl breaks out between Italian gangsters (including a wanted murderer named Luigi Orselli) and police officers. Officer Tom Conlin, aided by newspaper editor Captain Valento, places Orselli (played by an unknown actor) under arrest and is rewarded with five thousand dollars for his bravery. The film ends with the revelation that Irish Tom and Italian Tita will marry. The 
marriage will be administered by Irish Priest Father O'Reilly (it is interesting that in a neighbourhood that is predominately Italian, the priest is still an Irishman).

\section{Going Straight: The Irish and the Social Reform Narrative}

Although the subject was presented in a variety of ways, the social reform message always remained the same; that all members of society should make an effort to lead a crime-free, honourable life. A Boy of the Streets (Charles J. Hunt, 1927) tells the story of a safe cracker named Ned Duggan (Jonny Walker). In order to get enough money to send his younger brother (Mickey Bennett) off to the country and away from trouble, Irish-American Duggan plans to complete one last job. The task is to steal valuable documents from a safe and sell them to a crooked politician (Louis Wainright). Prior to the job Ned is injured in a freak accident and is taken to Mary Callahan's (Betty Francisco) house to be treated. Coincidently Mary's house happens to be the location of the safe Ned had planned on robbing. Ned, once recovered, goes ahead as planned but is caught in the act and subsequently arrested. Mary Callahan, understanding Ned's motive, rescues him from prosecution. In return, Ned aids the police in the arrest of the crooked politician. The film concludes with Ned vowing to abandon his criminal ways (Rockett 1996, 322-23).

When considering the onscreen Irish gangster in early American cinema, the most common period of discussion is the 1930s and 1940s. Films such as The Public Enemy (William A. Wellman, 1931) and Angels with Dirty Faces (Michael Curtiz, 1938) are frequently discussed in academic publications on the topic, such as Benshoff and Griffin's (2006: 61) America on Film. Yet, the onscreen Irish gangster can be found as far back as 1915 in reform story Regeneration (Raoul Walsh, 1915). Regeneration was based on a true story. The source material for the film was the autobiography of a reformed Bowery criminal named Owen Frawley Kildare. The autobiography centres on Kildare's transformation from an unschooled hoodlum to an honest man, under the guidance of a 'little school teacher' named Marie Deering. Two other screen versions were produced during the silent period, a Danish version named Det Morke Punkt (also titled The Call of a Woman) (August Blom, 1911) which Tony Tracey argues is the most accurate account of Kildare's story (2011, 414-21), and Fool's Highway (Irving Cummings, 1924).

The 1915 version starts with ten-year old Irish orphan Owen Conway (John McCann). After the death of his mother, Conway is taken in by neighbours in a rough tenement slum in New York City. However, the man is an abusive drunk and after he assaults Owen, the ten year old flees the home. At 17 years old (now played by Harry McCoy), he is working at the docks and makes extra money as a street fighter. At 25 years old (Rockliffe Fellowes) he becomes the leader of a tough gang. His actions lead him into direct confrontation with the assistant district attorney named Ames (Carl Harbaugh) who is determined to clean up the neighbourhood with the assistance of the upper-class Marie Deering (Anna Q. Nilsson). Owen falls for Marie and, and as a result, decides to help Ames when he is attacked by gang members. When Marie is shot by an associate of Owen, she makes him promise to abandon his criminal ways. The film ends with a reformed Owen standing at the grave of Marie. Tony Tracey has compared the ending of both the 1915 film and the 1908 stage play and notes how the concluding scenes differ in the two formats. In the stage version, 'Owen declares himself unworthy of Marie and allows himself to be led from the stage in handcuffs.' However in Walsh's film version, Tracey remarks, 'Owen visits Marie's grave in the film's final scene as an equal - in direct contrast to the play's conclusion, where she retains moral superiority. In the American cinema of 1915, Owen's working class Irishness is no longer insurmountably "other"” (2011, 422). 
The Irish-American gangster can also be found in Side Street (Malcolm St Clair, 1929), a 'talkie' crime drama that centres on an Irish-American family named O'Farrell. Both an Irish cop and an Irish gangster are members of the family. The film was described by a Beatrice Daily Sun reviewer as 'the outstanding film of the year' and was said to contain 'one of the most gripping and sensational climaxes ever portrayed in motion pictures' (Anon. 1929). Jimmy (Tom Moore) is a cop, John (Matt Moore) is a paramedic and Dennis (Owen Moore), unbeknown to the rest of the family, is a racketeer. They are the American-born sons (incidentally offering the only instance in which all three of the Irish-born Moore brothers feature in the same film) of Irish-born Nora (Emma Dunn) and Tom (Frank Sheridan) O'Farrell of County Kerry. Although the family have no idea where Dennis earns such a vast amount of money there is no indication that they suspect criminal activity. Tom bears some resemblance to the stage-Irish drunken paddy - he drinks a copious amount of alcohol at each family dinner and has the ability to smell it from a substantial distance. Other Irish characters include Kathleen Doyle (Katherine Perry), the love interest of Jimmy, and Kathleen's father Patrick Doyle (Walter MacNamara) who, like Tom, has a fondness for alcohol. It was not uncommon for the older Irish-born characters to contain elements of the stage-Irish character, even in the late 1920 s.

The narrative centres on Jimmy, who receives a promotion to detective and is assigned to a murder case involving the infamous Muller gang. During a party at the Muller house, one of the crooks is injured and when an ambulance answers the call, John (the paramedic) sees his brother Dennis at the house and discovers that he is Barney Muller, the notorious underworld leader, Dennis having used the alias to disguise his criminal activities from this family. John decides against telling any of the family members until he talks to Dennis. However, Kathleen, who had unwittingly attended the criminal gathering, tells Jimmy of her discovery. Gang members hear the conversation and decide to kill the detective. When Dennis learns of their plans he rushes to save his brother but is shot in the process. As he is dying he asks Jimmy and John for forgiveness, they oblige and his redemption is complete. Regrettably the quality of sound is not good, making it difficult to fully examine the dialogue. This is unfortunate as it is one of the earliest surviving talking pictures that includes both an Irish cop and Irish gangster within a reform narrative. Also notable is the inclusion of an IrishAmerican paramedic, a rare on-screen occupation for an Irish character during this early period of American cinema.

Irish gangsters can also be found in The Fighting Cub (Paul Hurst, 1925). The film centres on the exploits of a budding Irish journalist named Tommy O'Toole (Wesley Barry). The image of an Irish journalist seems to have been quite rare; How Molly Malone Made Good is the only other surviving film from the first three decades where this character can be found. Unfortunately, large parts of The Fighting $C u b$ are missing. The surviving scenes are held at the UCLA Film and Television Archive and depict a young red haired journalist trapped between his duty to his newspaper and his loyalty to a crooked politician named Toler (George Fawcett) - whose daughter (Mildred Harris) is the love interest of Tommy. Toler is associated with a ruthless mixed race gang (another example of the presence of the melting pot philosophy in early American cinema). They are led by an Irishman named Conner. Tommy, much like Molly in How Molly Malone Made Good, is depicted as dogged and brave, even getting in the way of gunfire to save Toler's life when the gang members turned against the crooked politician. Unfortunately the final scenes of the film are missing but if the film follows the formulaic 'social reform' narrative structure then it is likely that it ended with Tommy helping Toler to go straight and Tommy himself living happily ever after with a promotion and Toler's daughter's hand in marriage. It is likely that this ending would also signal the reformation of 
the gangster-controlled neighbourhood. In many ways the narrative of The Fighting Cub is similar to The Man in Blue. Both include ethnic stereotypes, crooked politicians and a love interest that is seemingly out of reach for the Irish character. The only notable difference is the presence of an Irish journalist in place the place of an Irish cop. While the relationship between Tom and Tita is a key part of the story in The Man in Blue, the principal component of the narrative is the reformation of a neighbourhood run by Italian crooks. The film relies on two established stereotypes to tell this reform story; the heroic Irish cop and the Italian gangster.

The Irish cop was one of the foremost recurring characters in early American cinema. A review of films produced between 1910 and 1930 shows that at least 30 productions contained an Irish Cop as a leading character (see Rockett 1996, 247-33). That figure excludes a large number of other films, such as The Line-Up at Police Headquarters (Frank Beal, 1914) where an Irish cop makes a fleeting appearance. In Little Annie Rooney (William Beaudine, 1925), Officer Rooney (Walter James), the local Irish cop and father to Annie (Mary Pickford), keeps the neighbourhood hoodlums under control while constantly encouraging them to adopt a life of integrity and honesty. By the end of the film two Irish gang members, Rooney's son Tim (Gordon Griffith) and gang leader Joe (William Hanes) have quit the gang and acquired honest jobs. The Irish cop was often depicted as a social mediator capable of controlling, as Martin McLoone puts it, 'the high-spirited Irish' (2008, 138). It is interesting that in The Man in Blue the Irish cop is shown to be capable of policing a neighbourhood dominated by Italians. By the 1920s the Irish enjoyed a relatively positive representation in comparison to other ethnic groups. In this instance the Irish cop is a supervisor of the Italian migrants. Even the Italian flower girl, Tita Sartori, while not depicted as negatively as the Italian crooks, can only achieve assimilation through her relationship with Irishman, Officer Tom Conlin - at one point claiming that Tom can help her remain in America. The Irish policeman's role is not only to reform the neighbourhood but also to guide the Italian residents in the assimilation process. Additionally, it is also an Irish man (Father O'Reilly) who will make this marriage (or in this case, integration) official. This idea ties into a statement made in the opening intertitle card of The Man in Blue, that refers to the inhabitants of Little Italy - 'Americans in the making, seeking to learn the new ways of the adoptive country.' It is the Irish, in this case, who are the educators. This idea, that the Irish regulate the Italians, not only applies to Officer Tom Conlin but also to his nephew (Pat), who wants to follow in Tom's footsteps and join the police force. In the opening scenes, whilst wearing a police hat and waving a baton, he regulates the Italian children as they drive their go-karts through the narrow streets. Pat (displaying the characteristics of the 'fightin' Irish man) gets into fist fight with a young boy who crashes his cart into a young girl's. The intertitle card that precedes this scene reads 'little Pat- already in training to rule America.' Even at such a young age, the Irish boy seems to be in training for the police force, supervising the Italian children.

\section{Conclusion}

As stated above, it is difficult to give a conclusive account of exactly how, when and why the onscreen Irish developed over the period this paper examines -though, as I have argued, the work of Olcott is a good place to start. Too many early films have been lost for the discussion to ever be complete. Therefore, this article is not the conclusive word on the subject but a contribution to the on-going discussion. Primarily, this paper asked, how were the Irish depicted between 1910 and 1930, and how did these representations compare to Irish depictions found in the foundational period of American cinema (1896-1910)? 
Although stage-Irish depictions would still appear sporadically, it is clear that the 1910s and 1920s were progressive years for the onscreen Irish. Recurring Irish characters in these years were unquestionably, and dramatically, more complex and positive than the earliest cinematic depictions. By the mid-1920s the onscreen Irish had attained a measure of respectability, and as such, the disparaging portrayals found in the earliest years were no longer commonplace. They were replaced by recurring images of ready-to-reform Irish criminals, honest Irish cops and tough, reliable Irish migrants. Narratives such as social reform, social transformation and the American melting pot philosophy carried underlying messages of assimilation that encouraged inter-class and inter-ethnic harmony and promoted hard work, integrity and valour as vital American ideals. The onscreen Irish played important roles in a significant number of these narratives. Two dominant characters typify the new positive representation of Irish men and women onscreen. The idiotic domestic servant had become the highly moral and socially aspiring Colleen character and the self-harming and buffoonish Irish labourer became the socially arbitrating Irish cop, a pillar of the community. Remarkably, in just two decades, the Irish went from the derogatory depictions of the stage to potential onscreen role models for the wider immigrant community. This striking improvement over such a short space of time makes the two decades covered in this paper a highly significant period in the on-going history of Irish representations. There has been no period since, in which American Cinematic depictions of the Irish has changed so dramatically.

\section{References}

Anonymous (1920) 'Cumings Theater Special Holiday Attraction', Fitchburg Daily Sentinel, 23 December, p. 16

Anonymous (1920a) 'Dinty is the Surprise Picture of the Year', The Kokomo Daily Tribune, 18 December, p. 5

Anonymous (1921) 'Molly O', The San Francisco Chronicle, 26 December, page unknown Anonymous (1924), Untitled film review, The Daily Star, 19 July, p. 7

Anonymous (1929), 'Side Street, Radio’s Smashing Picture Hit, Is Ritz Feature', Beatrice Daily Sun, 6 October, p. 1

Anonymous (1930) 'Short Subjects ', Film Daily, 26 January. p. 9

Anonymous (1930a) 'Fifth Cohens and Kellys', Film Daily, 12 March, p. 11

Fanning, D. C. (1961) 'Sidney Olcott in Ireland: A Memory of the Early Days of Filming', The Irish Times, 19 June, p. 8

Benshoff, H.M. \& Griffin, S. (2004) America on Film: Representing Race, Class, Gender, and Sexuality at the Movies, London: Blackwell Publishing

Lourdeaux, L. (1990) Italian and Irish Filmmakers in America, Philadelphia: Temple University Press

McLoone, M. (2008) Media, Film and Popular Culture in Ireland: Cityscapes, Landscapes, Soundscapes Dublin: Irish Academic Press

Meagher, T. J. (2009) 'Abie's Irish Enemy: Irish and Jews, Social and Political Realities and Media Representations', in R. Barton (ed.), Screening Irish-America: Representing Irish-America in Film and Television, Dublin: Irish Academic Press, pp. 45-58 
Mooney, J. (2013) 'The Irish in Vaudeville and Early American Cinema: 1865 - 1905,' PhD Thesis, Coleraine: Faculty of Arts of the University of Ulster

Pettitt, L. (2000) Screening Ireland: Film and Television Representation, Oxford: Manchester University Press

Rhodes, G. D. (2012) Emerald Illusions: The Irish in Early American Cinema, Dublin: Irish Academic Press

Rockett, K. (1996) The Irish Filmography: Fiction Films, 1896 -1996, Dublin: Red Mountain Press

Rockett, K. (2009) 'The Irish Migrant and Film', in R. Barton (ed.), Screening Irish-America: Representing Irish-America in Film and Television, Dublin: Irish Academic Press, pp. 17-44

Tracey, T. (2011) 'The Pauper and the Prince: Transformative Masculinity in Raoul Walsh's Regeneration', Film History: An International Journal, 23(4), 414-27

Whittaker, A. (1926) 'Glory to the Irish', Los Angeles Times, p. K15

\section{Filmography}

A Boy of the Streets (1927), directed by Charles J. Hunt, USA: Trem Car Pictures

Amarilly of Clothes-Line Alley (1919), directed by Marshall Neilan, USA: Mary Pickford Company Angels with Dirty Faces (1938), directed by Michael Curtiz, USA: Warner Brothers

A Wake in Hells Kitchen (1900), director unknown, USA: American Mutoscope and Biograph Brannigan Sets Off the Blast (1906), director unknown, USA: American Mutoscope \& Biograph Company

Caught by Wireless (1908), directed by Wallace McCutcheon, USA: Biograph

The Cohens and the Kellys film series (1926-1933), directed by various, USA: Universal Pictures

Conductor 1492 (1924), directed by Frank Griffin and Charles Hines, USA: Warner Brothers

The Courage of the Commonplace (1913), directed by Rollin S. Sturgeon, USA: Vitagraph

Det Morke Punkt (1911), directed by August Blom, Denmark: Nordisk Film

Dinty (1920), directed by John McDermott and Marshall Neilan, USA: Marshall Neilan Productions

The Duke of Dublin (1930), directed by William Watson, USA: Christie Film Company

The Fighting Cub (1925), directed by Paul Hurst, USA: Crown Productions

Fool's Highway (1924), directed by Irving Cummings, USA: Universal Pictures

For Ireland's Sake (1914), directed by Sidney Olcott, USA: Gene Gauntier Feature Players

Gone With the Wind (1939), directed by Victor Fleming, USA: MGM

Ham and Herring (1927), director unknown, USA: Weiss Brothers Artclass Pictures

How Bridget Made the Fire (1900), director unknown, USA: American Mutoscope \& Biograph Company

How Bridget Served the Salad Undressed (1898), director unknown, USA: American Mutoscope Company 
How Molly Malone Made Good (1915), directed by Lawrence B. McGill, USA: Photo Dram Company

Irene (1926), directed by Alfred E. Green, USA: First Nation Pictures

Irish Fantasy (1929), directed by Orville O. Dull, USA: Feature Productions

Irish Way of Discussing Politics (1900), directed by James H. White, USA: Edison

The Lad from Old Ireland (1910), directed by Sidney Olcott, USA: Kalem

The Line-Up at Police Headquarters (1914), directed by Frank Beal, USA: Nonpareil Feature Film Corporation

Little Annie Rooney (1925), directed by William Beaudine, USA: Mary Pickford Company

The Man in Blue (1926), directed by Carl Laemmle, USA: Universal

Molly O' (1921), directed by F. Richard Jones, USA: Mack Sennett-Mabel Norman Productions

Mother Machree (1928), directed by John Ford, USA: Fox

Paddy's Politic Dream (1916), directed by John Francis Dillon, USA: Vogue

The Public Enemy (1931), directed by William A. Wellman, USA: Warner Brothers

Regeneration (1915), directed by Raoul Walsh, USA: Fox

Rory O'More (1911), directed by Sidney Olcott, USA: Kalem

Shamus O’Brien (1908), directed by, Francis Boggs, USA: Selig Polyscope Company

Shamus O'Brien (1912), directed by Otis Turner, USA: Independent Moving Pictures

Side Street (1929), directed by Malcolm St Clair, USA: RKO

When Hooligan and Dooligan Ran for Mayor (1915), directed by Wally Van, USA: Vitagraph

When Women Vote (1907), director unknown, USA: Lubin 